\title{
Application of task-based approach in junior and high school English Teaching
}

\author{
Zhao Hui Min ${ }^{1, \text { a }}$ \\ ${ }^{1}$ Bohai university, Jinzhou, 121013 China \\ ahmzhao2008@163.com
}

\begin{abstract}
Keywords: Task based approach; junior high school application; oral English; teaching approach;
\end{abstract} innovative teaching methods.

\begin{abstract}
In daily communication, listening play an important role in English learning and listening is the most important channel to understand the language input. However, current English listening teaching in junior and high school is still not satisfying, and there are still many problems. Task based learning is a kind of teaching method, which is based on the specific task with learning motivation. Through classroom observation and teaching, this author explores the application of task based teaching in junior and high school listening teaching. The author applied task-based teaching method to the listening teaching in junior and high schools, and solved two main problems presented in junior and high school English listening teaching:
\end{abstract}

\section{Introduction}

In the past twenty years, the reform and opening up has played a huge role in promoting the rapid development of China's economy at the same time, will also Chinese to the world, so that the communication between China and the world more closely, English as the common language of the world of nature has attracted much attention and also requires high level of spoken English. Although the junior middle school students in our country have a good command of the basic knowledge of English, but they cannot really communicate. In the new stage of education reform, it is required to pay more attention to the cultivation and improvement of oral English, and to pay attention to the practicality of the language. But now the junior high school students pay more attention to the subject and the knowledge of the exam, not pay attention to oral English. In addition, because their English level is limited, often do not have enough confidence to say. The traditional English teaching mode is mainly based on the classroom teaching, the students have little chance to say, the school is not paid enough attention to the school, and the students themselves have gradually ignored the importance of oral English. It is concluded that there are many limitations in the oral English Teaching in junior high school in China, which needs to reform the teaching methods and improve the level of oral English teaching. There are four abilities in the acquisition of language [1], which are listening, speaking, reading and writing, but listening is the most difficult one among them. Most students are not interested in it, and at the same time, most students always lose confidence in dealing with the listening comprehension questions, because they think that their English is very poor. Therefore, it's necessary to review the current situation and existing problems of listening comprehension and combine the Task-Based Approach with the English Listening teaching. The Task-Based Approach as a new teaching approach of language appeared in the western world in the 1980s, and it emphasizes "learning by doing". Compared with traditional teaching methods, the Task-Based Approach can not only motivate the students 'interest, but can also help students to improve their English listening ability in the process of learning English. And then by this approach the students' learning efficiency and English application ability can be improved through cooperative learning and self-learning. 


\section{Task-based teaching theory}

\section{Task based teaching method.}

Task based teaching method is a teaching method based on the theory of pragmatism, often referred to as the task teaching method, this theory put forward by the American educator Dewey also pointed out that "doing" refers to the form of teaching, teaching is not taught by the teacher in the textbook knowledge as the main content, should be the focus to the students, let the students themselves in the activities of thinking comprehension and not just in the classroom by the teacher dictated. In the process of classroom teaching, teachers are required to make the teaching tasks and contents of each lesson, teaching and guidance according to the task, and finally achieve the teaching purpose. Classroom teaching mode like this is called task based teaching mode. Simply speaking, task-based teaching should focus on the communication between teachers and students in the classroom teaching process; pay attention to the activities in the process of the communication form; task oriented teaching in activities; ensure the authenticity of teaching in the process of teaching task; emphasize the project in the process of designing homework; review focus on the process of teaching evaluation. Task based teaching method is a teaching method which aims at improving the quality of classroom teaching. The constructivism principle indicates that teachers' teaching activity must be scheduled problems and tasks as the basis; to guide students to think, to encourage students to actively explore, cultivate students' curiosity; optimize the teaching environment, to ensure its authenticity, let the students with the task of thinking; encourage students to have the ability of independent research, positive analysis thinking about the problem. The task teaching method is not only the teacher give students assignments, but asked the teacher according to the design of interlocking steps of the student's own characteristics, to ensure that the knowledge points of coherence, and effectively guide the students to think independently. So that students in the course of the teacher to complete the task, in person to find the answer to the question, to deepen the understanding of the knowledge and impression [2]. The most important part of the task based approach is the task, the teacher carefully assigned tasks to ensure that the desired teaching purpose is achieved.

\section{The studies of listening comprehension.}

Listening is a cognitive activity and language skills, and plays an important role in our daily life and language learning, and at the same time, listening comprehension has increasingly become an important criterion to measure the level of learners' language study (Long, 1993). But according to our longtime observation and study on the teaching practice, the traditional English listening teaching methods used in china inhibit the students' listening ability to improve. Listening comprehension research includes five aspects, they are listening materials, speakers, tasks, learners and listening processes (Richards and Platt, 1992). The degree of difficulty about the listening material and listeners' familiarity; the rate of speech, voice, expression of speakers.

\section{The studies of the application of Task-Based Approach to listening class.}

The Task-Based Approach appeared in the 1980s. It aims to language teaching real and classroom socialization. The Task-Based Approach is a task or an activity for a particular purpose (Crookes, 1989). In educational curricula, it is mainly used to collect data for research. In the process of language learning, task is a communication activity, and also a kind of language practice which emphasizes "learning by doing". The core of the Task-Based Approach is the "learner-centered" and "people-oriented", and the theoretical basis is the "constructivist".The task is composed of five parts, which are the teaching aims, inputs, and forms of activities, the role of teachers and students, and the environment (Nunan, 1989). The Task-Based Approach emphasizes that learners not only focus on the language, but also focus on the process of language learning, and it emphasizes the interaction and cooperation in the process of learning, and also emphasizes the process and results. Task-Based Approach use the relatively realistic tasks to make students complete the task in group discussion or role-playing and other activities, and then strengthen the interaction between teachers and students, motivate students' learning interest, mobilize the students' positive emotional factors, and cultivate 
students' awareness and cognitive abilities. At the same time, Task-Based approach also inspires the students to share their individual experience since they have to complete their task in groups, and then train them to understand, operate and use language. Extensive, in-depth, and complex language using has been fully reflected through the process of completing a task. Therefore, the Task-Based Approach has its own unique merits from its teaching aims or from its teaching model, because the Task-Based Approach not only has the advantages of traditional teaching methods but also has the advantages of the communicative teaching approach [3].

\section{The feasibility of applying task based approach to oral English Teaching in junior middle school}

\section{Deficiency of traditional oral teaching.}

The traditional method of oral English Teaching in junior school is mainly dictated, students practice and communication, referred to as the "3P" mode, the teacher first of key words and sentences to explain, then the organization patterns of students practice, let students role to express and exchange. Although this model is easy to practice, it is beneficial for teachers to control the teaching process and the classroom, students can understand most of the points of knowledge, and sentence patterns can also get the actual practice and expression. However, at this stage, the community to improve the requirements of spoken English, "3P" model gradually problems. The obvious disadvantages as follows: it destroys the relationship of combination of theory and practice, the importance of paying too much attention to sentence explanation and ignore the other; practice is limited to imitate, not really to cultivate students' autonomous ability; "3P" model will dictate, students practice and communicate these three parts separately, not to realize the goal of language learning. Only this kind of teaching mode to a certain extent, help students accumulate basic knowledge of grammar, and cannot really improve the students' oral expression ability, all activities of the student are all teachers, students in a passive state, the lack of learning initiative.

\section{The advantages of implementing task based Teaching.}

First, task based teaching has its own advantages, it not only adapts to the characteristics of junior high school English teaching, but also in accordance with the current stage of the reform of junior high school oral English teaching. The characteristics of task-based teaching method is the most true, requires teachers to design the teaching task according to the actual situation of the students, requires students to personally to discover, through thinking, team or group cooperation, together to explore and solve the problems in personal communication, language expression ability. All of these activities are student centered, students don't have to worry about making mistakes, we check each other, help to improve complete tasks assigned by the teacher. As a result, not only to enhance the courage to speak, but also to stimulate the enthusiasm of students learning. Second, the task-based teaching method does not require teachers with high professional quality and skills of the school teaching requirements are not high, junior middle school English teachers have enough quality and ability to carry out this teaching method, not only save manpower, but also improve the students' oral English ability. In addition, a lot of teachers in addition to impart knowledge, but also to continue the forefront of research, can promote the rational operation of the task based teaching method.

\section{The problems in teaching materials.}

In the listening teaching of English in junior high school, the most important problem that troubles teachers lies in the listening materials. And there are two main problems in the listening materials. Firstly, the listening materials usually used by teachers are written language rather than spoken English, so it is difficult for English learners to understand. Certainly, one cannot deny that there is a lot of spontaneous teacher-talk during class, but it is not enough to improve learners' English listening ability. Secondly, the contents of the materials often do not match the real life. Many listening comprehension books usually include many long passages rather than dialogue and most of them beyond the learners' ability. After listening, they have to do some comprehension exercises, 
usually multiple-choice. This teaching approach provides a certain type of practice, but it is not related to our real life. So the course of the listening comprehension is so boring to students. There is no doubt that the English leaner cannot improve their listening ability [4].

\section{The Problems of Classroom Teaching Model.}

In junior high school, most teachers usually prepare listening materials before starting listening class. They usually use a similar way to teach, they often play the tape several times, if students cannot understand or memory the main idea of the listening materials, and teachers often repeat the materials again and again. And teachers help students by explaining the difficult sentences. Finally, teachers usually check and correct the answers students have done, this is not a class of listening but a class of testing students' memory, so most of the students are very tired after class. These methods of teaching not only fail to improve students' listening ability but also make them lose confidence and interest of listening. This kind of class ignores students' motivation to learn, and never be able to arouse students' interest, also depresses the atmosphere and the fillings of students. The most important problem is that students do not have any chance to communicate in natural languages, let alone knowing about the characteristics about real-life communication. From the method of teaching their teacher using, students don't get any comments from their teacher, as a result this teaching method is not satisfied by many English learners.

\section{The application of task based teaching method in junior high school English}

\section{Design assignment.}

Task teaching method is the first to do, but also the most important step is the actual task, the task of the design of science or not, directly related to the task of the results and achievements. Therefore, before the task design, detailed understanding of the basic knowledge and practical ability of students, but also to take into account the interests of students, etc., and then carry out the task design. In addition, the form of design tasks should be a level, set a few small goals in the big goal, to achieve these small goals and then complete the total task. The design task should be based on the teaching purpose and the actual situation, reasonable design knowledge point distribution, cannot be too high or too low, otherwise cannot achieve the best teaching effect. In this paper, the English sentence "will you do on What" as an example of the specific implementation of task-based teaching method, set up the exercise task, in the process of the task of training students to explore, understand and the ability to express their own[5].

\section{Concrete implementation method.}

You design a reasonable task plan, the next step is the implementation of specific process, and this process should not be overlooked. This process not only refers to the teacher's inspiration to students, it is the first step to students' autonomous learning and exploration, not only to improve students' ability to think independently, but also to stimulate students' interest in learning.

(1) to encourage students to tell what activities are planned for tomorrow, such as: Students to listen Encourage Music to, television watch, read, and games and do some exercise play, etc?

(2) statistical data make the form.

(3) group activities: a group of 5 students in a group on the contents of the table to ask each other, answer, and make a record.

(4) according to the table for statistical analysis, calculation of the proportion of the activities.

(5) to analyze the results of the statistics, and organize the students to report on the results of the group as a unit, and discuss the reasonable proportion of the activities.

\section{Summary}

After a certain period of the results of the analysis of the teaching practice, it is feasible to apply the task based approach in oral English Teaching in junior high school. This teaching mode has 
certain teaching purpose, and it is good for stimulating students' learning enthusiasm. After the completion of the task, the students enhance their self-confidence and deepen the impression of knowledge. The survey results in each group show when students can learn from each other in the process of sharing, find their own shortcomings, to find the gap, to stimulate the students' morale. As a result, not only for students to improve their oral communication skills in a happy event, but also to cultivate their enthusiasm for learning, but also let them feel the strength of unity. This teaching method is in accordance with the requirements of junior high school English teaching reform, which is conducive to the reform of teachers' teaching ideas, and it has obvious feasibility. Therefore, all schools in our country should absorb the essence, make full use of excellent and reasonable teaching methods, improve teaching efficiency, and achieve the ultimate goal of talent training.

\section{Acknowledgements}

This work is supported by Social Science Foundation of Liaoning Province (No. L15DWW005) and Bohai University Teaching Reform Project (No.BDJG15QNB002).

\section{References}

[1] on bamboo Qin application [J]. Journal of Hunan University of Science and Engineering. In Higher Vocational English Teaching in the task-based teaching method. 2016 (08).

[2] management of the task based teaching method in the teaching of oral English in the design and research [J]. Journal of Qiqihar Teachers College. 2016 (03).

[3] Yin Suiqiong. Personality influence on English learning [J]. Crazy English task-based teaching method (THEORY EDITION). 2016 (02).

[4] Wang Lu, Bowie Tseng, Mr. bell, al. The reform of College English teaching effect on vocabulary classroom activities students' perception of [J]. architecture and contemporary educational theory and practice 2016 (07).

[5] Li Zhe. Observation of [J]. education training of intercultural communicative competence and task-based teaching method in College English Teaching (the first half) 2016 (08). 